\title{
Comparison of Protein Profile and Peroxidases in Bush and Vine-type Tropical Pumpkin
}

\author{
Tao Wu and Jiashu Cao' \\ Institute of Vegetable Science, Zhejiang University, 268 Kaixuan Road, Hangzhou 310029, China
}

AdDitIonAl INDEX words. Cucurbita moschata, dwarf, native PAGE, near-isogenic line, SDS-PAGE

\begin{abstract}
Comparisons of total peroxidase activity and peroxidase isozymes as well as protein profiles among segregating, near-isogenic bush and vine phenotypes of pumpkin (Cucurbita moschata Duchesne) were investigated. Peroxidase activities of internode and leaf tissues of the bush plants were higher than those of respective vine tissues. Roots of bush plants, however, had a lower peroxidase activity than vine plants. In both bush and vine plants, peroxidase activities were lower in leaf tissues than in root and internode tissues. Electrophoretic comparisons revealed qualitative differences in peroxidase patterns in internodes between bush and vine plants. Moreover, qualitative differences between internode and root profiles were found between bush and vine plants in $C$. moschata. In conclusion, the results of this report revealed that a single gene conferring the bush phenotype in $C$. moschata might affect the relative expression of peroxidase activity, peroxidase isozymes, and protein profiles in leaf, internode, and root tissues.
\end{abstract}

Peroxidases (EC 1.11.1.7) have many physiological roles in several primary and secondary metabolic processes, such as scavenging of peroxide, participation in lignification, regulation of cell growth and differentiation, hormonal signaling, plant defense, indol-3-yl-acetic acid (IAA) catabolism, oxidation of toxic compounds, and ethylene biosynthesis (Campa, 1991). The plant cell wall is a very dynamic structure which controls both cell shape and cell elongation. Various enzymatic processes cleave and re-assemble the cell-wall constituents during cell extension. Changes in the cell-wall architecture can be achieved by class III peroxidases through their two catalytic cycles: peroxidative and hydroxylic (Passardi et al., 2004). They can stop elongation by forming bonds within the cell wall or favor it by regulating the local concentration of $\mathrm{H}_{2} \mathrm{O}_{2}$ or by generating reactive oxygen species (ROS), which break cellwall bonds (Passardi et al., 2004). Indirectly, peroxidases can also control the cell elongation through their auxin oxidase activity. IAA can be oxidized by following two different mechanisms: 1) a conventional hydrogen peroxide-dependent pathway and 2) one that is hydrogen peroxide-independent and requires oxygen (Savitsky et al., 1999). By this way, peroxidases might locally regulate auxin concentration. In parallel, peroxidase expression levels are dependent on the endogenous auxin concentrations (Gaspar et al., 1996). Investigators have found multiple forms of peroxidase in numerous plants including several species of dwarf plants (Evans and Alldridge, 1965; Kamerbeek, 1956; Loy, 1967; McCune, 1961). Several species of genetically dwarf plants have been reported to have a higher peroxidase activity than their nondwarf or normal counterparts (Evans and Alldridge, 1965; Kamerbeek, 1956; McCune and Galston, 1959; Van Overbeek, 1935). It has also been shown that several peroxidase isozymes are quantitatively altered by gibberellic acid application to dwarf plants (Birecka and Galston, 1970; McCune, 1961; Shanan, 1976). These observations, together with the known catalytic properties of peroxi-

Received for publication 24 July 2007. Accepted for publication 17 Feb. 2008. This work was supported by the Natural Science Foundation of China (No. 30270909).

${ }^{1}$ Corresponding author. E-mail: jshcao@zju.edu.cn. dase, led to their implication in the physiology of dwarfing (Loy, 1972; Van Overbeek, 1935). In a comparison of the total peroxidase activities and isozyme patterns between the bush and vine types of Cucurbita pepo L. and Cucurbita maxima Duchesne (squash), Cucumis melo L. (muskmelon), and Citrullus vulgaris Shrad. (watermelon), Loy (1967) found no significant differences in the peroxidase activities or isozyme patterns between bush and vine types. The results of Loy (1972) revealed that the overall genotype of squash cultivars could influence the relative expression of peroxidase activity between bush and vine forms. However, peroxidase differences between bush and vine plants in $C$. moschata were not investigated.

$\mathrm{Wu}$ et al. (2007) selected a bush-type plant from C. moschata. Bush plants were characterized by shorter internodes, earlier flowering, a higher ratio of female to male flowers, and smaller fruit than vine plants. Genetic analysis indicated monogenic inheritance with the bush genotype dominant. Furthermore, a study by Cao et al. (2005) revealed that the bush plant in C. moschata reported by Wu et al. (2007) was a gibberellin-responsive mutant and that the bushy appearance was the result of inhibition of cell elongation. The aim of this study was to compare the total peroxidase activities and peroxidase isozymes as well as the protein profiles between bush and vine-type phenotype in a near-isogenic line of C. moschata bush plants.

\section{Materials and Methods}

Plant material. Near-isogenic plants (five backcrosses) of $C$. moschata segregating $1: 1$ for bush and vine phenotypes were used is this study. The vine parent $(\mathrm{CgaV})$ was used as the recurrent parent. The seedlings of the bush and vine plants could be distinguished at the third-leaf stage. Seeds were sown on 16 Mar. 2006, with the seedlings grown in a mixture of 1 vermiculite : 1 perlite (by volume) at the research farm of the Institute of Vegetable Science at Zhejiang University, Hangzhou, China. At the two- or three-leaf stage, seedling roots were washed gently in water, and then four plants were transplanted into a plastic pot containing $8 \mathrm{~L}$ of Japan Yuanshi (JY) nutrient solution (Yu and Matsui, 1997): $14 \mathrm{~mm} \mathrm{~N} \mathrm{[4.0} \mathrm{mm} \mathrm{KNO} \mathrm{KN}_{3}$, 
$\left.4.0 \mathrm{~mm} \mathrm{Ca}\left(\mathrm{NO}_{3}\right)_{2}, 2.0 \mathrm{~mm} \mathrm{NH}_{4} \mathrm{H}_{2} \mathrm{PO}_{4}\right], 2.0 \mathrm{~mm} \mathrm{P}\left(\mathrm{NH}_{4} \mathrm{H}_{2} \mathrm{PO}_{4}\right)$, $4.0 \mathrm{~mm} \mathrm{~K}\left(\mathrm{KNO}_{3}\right), 4.0 \mathrm{~mm} \mathrm{Ca}\left[\mathrm{Ca}\left(\mathrm{NO}_{3}\right)_{2}\right]$, and $2.0 \mathrm{~mm} \mathrm{Mg}$ $\left(\mathrm{MgSO}_{4}\right), 3.0 \mathrm{mg} \cdot \mathrm{L}^{-1} \mathrm{Fe}$ (Fe-EDTA), $0.5 \mathrm{mg} \cdot \mathrm{L}^{-1} \mathrm{Mn}\left(\mathrm{MnSO}_{4}\right)$, $0.5 \mathrm{mg} \cdot \mathrm{L}^{-1} \mathrm{~B}\left(\mathrm{H}_{3} \mathrm{BO}_{3}\right), 0.05 \mathrm{mg} \cdot \mathrm{L}^{-1} \mathrm{Zn}\left(\mathrm{ZnSO}_{4}\right), 0.05 \mathrm{mg} \cdot \mathrm{L}^{-1}$ Mo $\left[\left(\mathrm{NH}_{4}\right)_{6} \mathrm{Mo}_{7} \mathrm{O}_{24}\right]$, and $0.02 \mathrm{mg} \cdot \mathrm{L}^{-1} \mathrm{Cu}\left(\mathrm{CuSO}_{4}\right)$. The $\mathrm{pH}$ of the nutrient solution was adjusted to 5.8 with $1 \mathrm{~m} \mathrm{NaOH}$, and the solutions were changed weekly. Polyurethane foam and a plastic mesh supported the seedlings, which grew under controlled environmental conditions. Plants were grown under supplementary lights with an irradiance of $90 \mathrm{~W} \cdot \mathrm{m}^{-2}$ and a $12-\mathrm{h}$ photoperiod. Air temperature was $22-24{ }^{\circ} \mathrm{C}$, and relative humidity was $75 \%-90 \%$. Samples (internodes, leaves, and roots) were randomly collected from 10 seedlings of each type at various times after germination $(20,24,28,32$, and $36 \mathrm{~d})$. The third internode of vine plants at different development stages was collected. However, in bush plants, we collected their first internode at different development stages because of their bush character. Experiments were carried out with the leaves of the middle (the third) story of the bush and vine type plants at different stages of their development. Primary roots of the bush and vine plants were also collected at different stages of their development. Samples were weighed, immediately frozen in liquid nitrogen, and then stored at $-80{ }^{\circ} \mathrm{C}$ until use.

Protein and ENZYMe eXtraction. Enzyme extracts were prepared by homogenizing the samples $(500 \mathrm{mg})$ in a prechilled mortar and pestle nestled in ice along with 5\% polyvinylpyrrolidone and $1 \mathrm{~mL}$ of chilled extraction buffer consisting of 50 mм potassium phosphate ( $\mathrm{pH} 7.5)$ buffer and 1 mм EDTA. The homogenate was centrifuged (Sorvall ULTRA 80; Thermo Fisher Scientific, Waltham, MA) at $12,000 g_{\mathrm{n}}$ for $15 \mathrm{~min}$ at $4{ }^{\circ} \mathrm{C}$. Supernatants were then collected for subsequent protein and enzyme assays immediately following extraction. Protein concentration was measured by the spectrophotometric method of Bradford (1976) using the Bio-Rad Protein Assay Dye Reagent Concentrate (catalog no. 500-0006; Bio-Rad, Hercules, CA). Enzyme activities based on total protein were determined spectrophotometrically (Lambda 40; PerkinElmer, Waltham, MA) at $25^{\circ} \mathrm{C}$.

Peroxidase activity determination. Peroxidase activity was measured in a reaction mixture $(3 \mathrm{~mL})$ containing $10 \mathrm{~mm}$ potassium phosphate buffer, $\mathrm{pH} 7.0,10 \mathrm{~mm} \mathrm{H}_{2} \mathrm{O}_{2}$ solution, 20 mm guaiacol, and $10 \mu \mathrm{L}$ of crude extract (Maehly and Chance, 1954). Absorbance was measured over a 5-min time interval at $470 \mathrm{~nm}$ after starting the reaction with addition of $\mathrm{H}_{2} \mathrm{O}_{2}$. The specific activity of peroxidase was expressed as units per milligram of protein per minute $\left(\mathrm{U} \cdot \mathrm{mg}^{-1} \cdot \mathrm{min}^{-1}\right)$.

Native polyacrylamide gel electrophoresis (PAGE) AND ISOZYME STAINING. Discontinuous electrophoresis was performed with a MiniProtean electrophoresis unit (AE-6220; ATTO, Tokyo) using $2.5 \%$ stacking gel and $7.5 \%$ running gel. Equal amounts of protein from each sample underwent electrophoretic separation (Tris-glycine buffer, $\mathrm{pH} 8.3,80 \mathrm{~V}$ for 30 min, and then $120 \mathrm{~V}$ for $3 \mathrm{~h}$ at $4{ }^{\circ} \mathrm{C}$ ). Peroxidase isozyme bands were detected by incubating gels for about $10 \mathrm{~min}$ in a solution composed of $5.8 \mathrm{~mm} o$-dianisidine dissolved in $95 \%(\mathrm{v} / \mathrm{v})$ ethanol, $7 \mathrm{~mL}$ of sodium acetate/acetic acid buffer, $\mathrm{pH} 6.0$, and $500 \mu \mathrm{L}$ of $3 \%(\mathrm{~m} / \mathrm{v}) \mathrm{H}_{2} \mathrm{O}_{2}$ solution. Staining took place in sodium acetate/acetic acid, $\mathrm{pH}$ 5.0, followed by washing the gels with distilled water (Brewbaker et al., 1968).

SOdium DOdeCYL SULFATE-POLYACRYLAMIde GEL ELECTROPHORESIS. SDS-PAGE facilitated the protein profile analysis according to a method described by Laemmli (1970), using a $12 \%$ acrylamide resolving gel $(0.375 \mathrm{~m}$ Tris- $\mathrm{HCl}, \mathrm{pH}$ $8.9)$ and $4 \%$ stacking gel $(0.125 \mathrm{M}$ Tris- $\mathrm{HCl}, \mathrm{pH} 6.8)$. The running buffer was Tris-glycine $(0.3 \%$ Tris base, $1.44 \%$ glycine, and $0.1 \%$ SDS, $\mathrm{pH} 8.3$ ). Electrophoresis on the SDS-polyacrylamide gel was performed using a vertical gel electrophoresis apparatus. Samples $(500 \mathrm{mg})$ were ground in $0.5 \mathrm{~mL}$ of $250 \mathrm{~mm}$ Tris- $\mathrm{HCl}$ buffer (pH 6.8, containing $0.1 \%$ $\beta$-mercaptoethanol) and centrifuged at $12,000 g_{n}$ at $4{ }^{\circ} \mathrm{C}$ for $20 \mathrm{~min}$. Protein extracts were then transferred to an equal volume of sample buffer (Laemmli's $2 \times$ buffer), heated at $100{ }^{\circ} \mathrm{C}$ for $3 \mathrm{~min}$, cooled, and then used in SDS-PAGE. An aliquot containing $50 \mu \mathrm{g}$ of sample protein was loaded in each well. After completion of electrophoresis, the gels underwent staining with $0.03 \%$ Coomassie Brilliant Blue G250, followed by destaining with 1 acetic acid : 1 methanol : 8 distilled water solution (by volume). Proteins used to determine molecular weight (MW) were bought from Shanghai Sangon Biological Engineering Technology and Services Co., Ltd. (Shanghai, China). Each experiment was repeated three times, and the same trends of results were obtained.

Statistical analyses. The data were analyzed by an analysis of variance (ANOVA) using DPS (version 7.05; Ruifeng Info Technology Ltd., Hangzhou, China). Mixed samples were randomly collected from 10 seedlings of each type. Four replications per plant type were used. One experiment used four spatial replications per plant type with measurement date as a block. Data means and standard errors were then averaged from four repeated experiments.

\section{Results}

Bush plants had higher leaf and internode peroxidase activity than vine plants, while the latter had higher root peroxidase activity than bush plants (Fig. 1). Significant differences

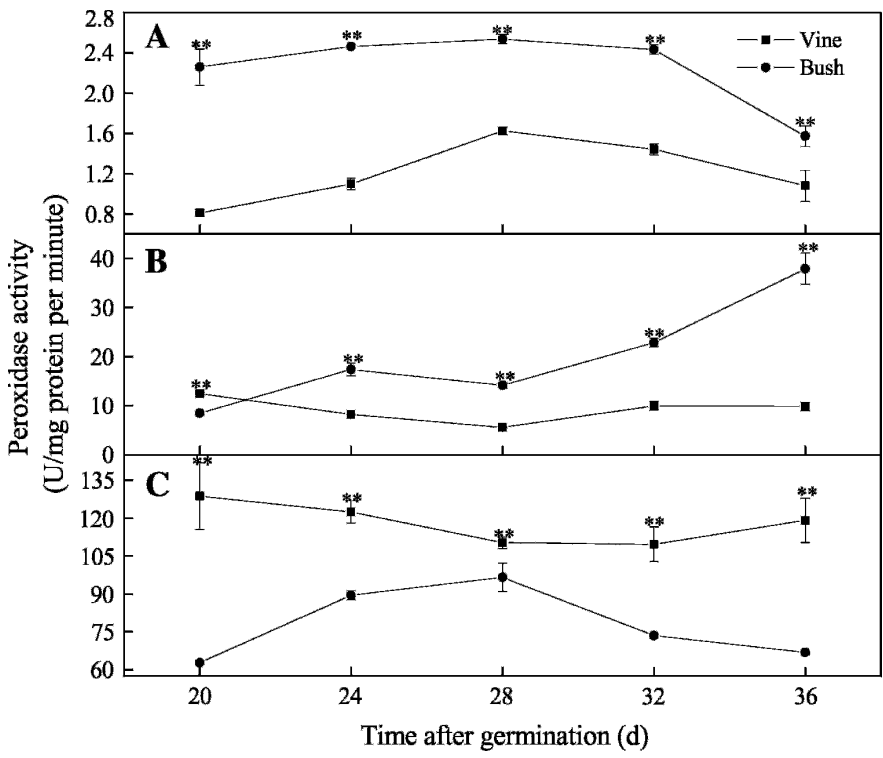

Fig. 1. Changes in the activity of peroxidase in the leaf (A), internode (B), and root (C) of bush and vine-type plants in Cucurbita moschata. The first internode of bush plants and third internode of vine plants were sampled. All the data obtained were averaged values from four repeated experiments. The means and SE derived from four repeated experiments are presented; **significant at $P<0.01$. 
in leaf peroxidase activity were observed between the two analyzed phenotypes. In vine plants, peroxidase activity of leaf increased from 20 to $28 \mathrm{~d}$ and then decreased at the latter sample stages (Fig. 1A). The results also showed significant differences in peroxidase activities between bush and vine genotypes at all developmental stages both in the internode and in the root. There was little change in peroxidase levels in vine internodes, and in bush internodes there was a slight increase from 20 to $28 \mathrm{~d}$ followed by a steep increase from 28 to $36 \mathrm{~d}$ (Fig. 1B). Root peroxidase activity showed a different trend for the two phenotypes. A gradual increase was observed in bush plants from 20 to $28 \mathrm{~d}$ and then a decrease in peroxidase activity was found, while in vine plants, a decrease was found from 20 to $32 \mathrm{~d}$, followed by a slight increase (Fig. 1C).

Because changes in enzyme activities may be reflected in qualitative changes in isoenzymes, changes in peroxidase isozyme patterns during the development of bush and vine plants in C. moschata were also investigated. Each organ had a characteristic isozyme pattern. Roots exhibited a strongly expressed isozyme 1, leaves exhibited isozymes 1 and 2, and internodes exhibited five isozymes. Individual comparisons of the peroxidase isozymes between bush and vine plants in $C$. moschata revealed no qualitative differences in root and leaf (Fig. 2A and B). In roots, both bush and vine plants expressed isozyme 1 , the only major peroxidase isozyme detected, and expression of this isozyme was similar at the different developmental stages (Fig. 2A). In leaves, isozyme 1 was weakly expressed and isozyme 2 showed variable expression in bush and vine plants at all developmental stages (Fig. 2B). The internode peroxidase in bush and vine plants showed some qualitative and quantitative differences (Fig. 2C). Isozyme 3 was usually not expressed at $20 \mathrm{~d}$, and it showed variable expression in bush and vine genotypes during the different
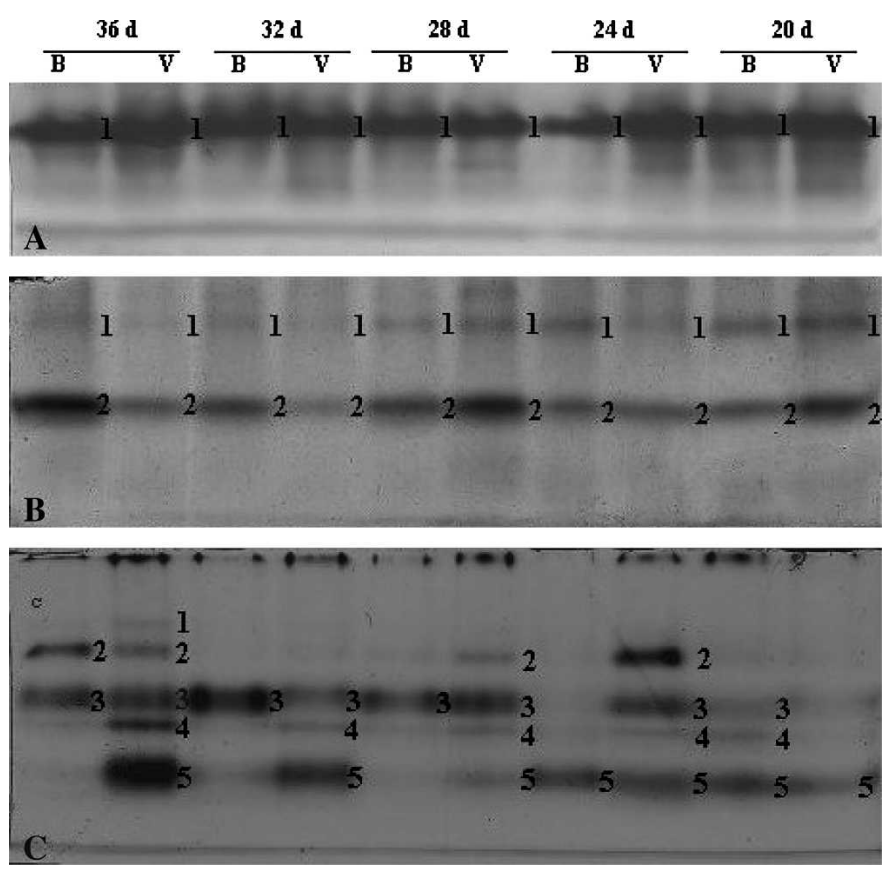

Fig. 2. Peroxidase isoenzymes in the root $(\mathbf{A})$, leaf $(\mathbf{B})$, and internode $(\mathbf{C})$ of bush and vine-type plants collected at five different sampling stages $(20,24$, 28, 32, and $36 \mathrm{~d}$ after germination) in Cucurbita moschata. Experiment was repeated three times, and the same result trends were obtained; $\mathrm{B}=$ bush plants, $\mathrm{V}=$ vine plants. developmental stages. Isozyme 5 was more intense in bush than in vine plants at 32 and $36 \mathrm{~d}$. Isozyme 4 usually was detected only in vine plants. Isozyme 5 was more strongly expressed in vine than in bush plants at later stages of development.

According to the SDS-PAGE analysis, the protein profiles in the root, leaf, and internode of C. moschata plants were similar, but some differences could be detected (Fig. 3). In the comparison of root proteins (Fig. 3A) between vine and bush plants, a protein band between 31.0 and $43.0 \mathrm{kDa}$ (shown by arrow) appeared to be restricted to vine plants, and another moderately expressed band between 20.1 and $31.0 \mathrm{kDa}$ was expressed only in bush plants (Fig. 3A). The banding patterns of leaf proteins were the same between the two phenotype plants (Fig. 3B). A specific protein with a molecular mass of 31.0$43.0 \mathrm{kDa}$ was found in the internode of vine plants as compared with that of bush plants (Fig. 3C).

\section{Discussion}

By comparing total peroxidase activities between nearisogenic bush and vine plants of $C$. moschata, we found that the internode and leaf peroxidase activities of bush plants were higher than those of respective vine tissues. The bush root, however, had lower peroxidase activity than its vine counterparts. In our study, because vine plants grew faster than bush plants, we compared peroxidase levels using the first internode of bush and the third internode of vine plants. The differences reported herein could be a function of developmental stage examined; however, the higher levels in bush plants were observed in internodes examined from 24 to $36 \mathrm{~d}$ of germination. These results agree with those of Evans and Alldridge (1965) in tomato (Solanum lycopersicum L.) and more or less with those of McCune and Galston (1959) in corn (Zea mays L.), whose results differed according to substrate used. Considering that the bush plants in C. moschata have a monogenic inheritance (Wu et al., 2007), the total peroxidase activity comparison in this report revealed that expression of peroxidase activity in bush or vine forms might be altered by the genotype of C. moschata. Moreover, in our study comparing peroxidase isozymes, both qualitative and quantitative differences in isozyme expression in internodes of bush and vine plants were detected at different stages of development. McCune (1961) determined peroxidase activities for six isoperoxidases in one normal and four dwarf corn genotypes and reported in most instances that dwarf plants had higher levels than vine plants. Siegel and Galston (1967) compared the heterogeneity of the peroxidases between tall and dwarf cultivars in peas (Pisum sativum L.) and reported that each organ had a characteristic isozyme pattern and that the band patterns in the corresponding organs from different cultivars were far more alike than were the patterns in the different organs within each cultivar. Our results contrast with those of Loy (1972) who found no significant differences in the total activity of stem peroxidases of bush and vine isogenic lines of C. pepo 'Table Queen' and no differences in cathodic and anodic isoperoxidase patterns. We should also point out that the buffer system used in our electrophoretic studies was used to separate only acidic (anodic migrating) peroxidases.

Total-elongating internode peroxidase and isozyme comparisons between the bush and vine plants of $C$. moschata might be more meaningful than leaf and root peroxidase and isozyme comparisons. Cao et al. (2005) revealed that the bush plant in 


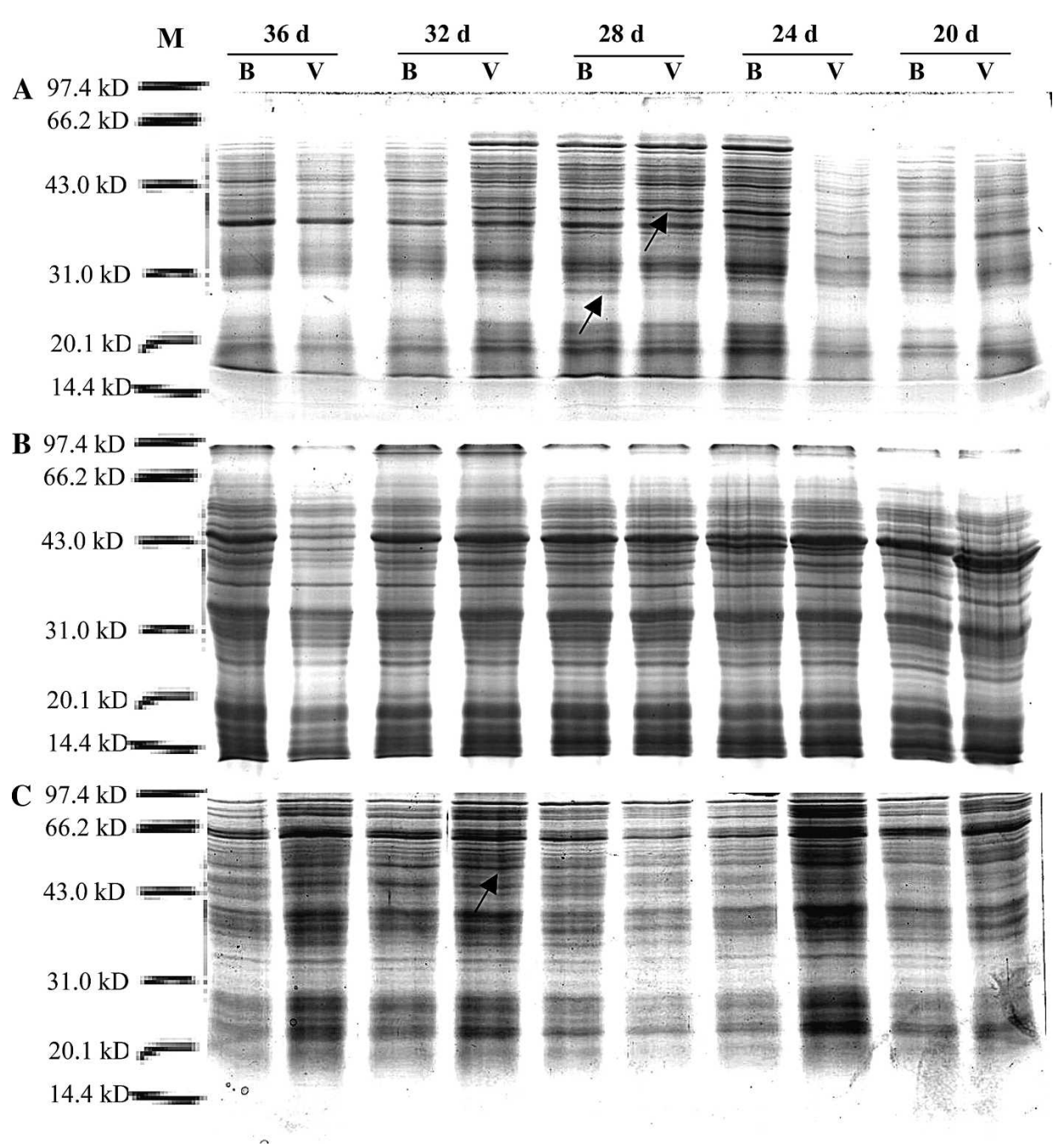

Fig. 3. SDS-PAGE pattern of proteins in the root (A), leaf (B), and internode $(\mathbf{C})$ of bush and vine-type plants collected at five different sampling stages (20, 24, 28, 32, and $36 \mathrm{~d}$ after germination) in Cucurbita moschata. The first internode of bush plants and third internode of vine plants were sampled. The experiment was repeated three times, and the same result trends were obtained. Arrows indicate new or strongly expressed bands; $\mathrm{B}=$ bush plants, $\mathrm{V}=$ vine plants, $\mathrm{M}=$ molecular mass marker.

C. moschata was a gibberellin-responsive mutant, and so differences in peroxidase levels and isoperoxidase patterns may reflect the action of GA on development. Previous studies showed that gibberellic acid application to dwarf corn plants quantitatively altered several peroxidase isozymes (McCune, 1961; Siegel, 1955). The studies of Birecka and Galston (1970) found decreased peroxidase activity in the gibberellic acidtreated internodes of dwarf pea stem, whose elongation was promoted by the hormone. However, upon cessation of growth, the peroxidase activity of the treated plants increased over the controls. Meanwhile, the report of Shanan (1976) revealed that the treatment of dwarf bean (Phaseolus vulgaris L.) plants with gibberellic acid $\left(\mathrm{GA}_{3}\right)$ produced a characteristic stem elongation accompanied by a decrease in peroxidase activity. Increasing concentrations of $\mathrm{GA}_{3}$ and time after treatment led to increases in stem elongation and lignification but to a decrease in peroxidase activity.

The result of SDS-PAGE revealed that different tissues and organs possessed different protein profiles (Fig. 3). Furthermore, the protein band intensities were different in all of the tissues investigated. The bush and vine plants had banding patterns with close similarity. However, there were three instances in which a specific band was detected only in one phenotype or the other. The SDS-PAGE result revealed that the specific band might have a high correlation with bush in C. moschata. Future work will therefore involve isolating and sequencing the special bands as well as investigating the function of these proteins.

In conclusion, this is the first investigation of total peroxidase activities and peroxidase isozymes, as well as protein profiles between bush and vine-type plants in C. moschata. Differences in peroxidase levels and peroxidase isozymes between near isogenic cultigens of C. moschata may relate to the effect of the dwarf gene on gibberellin action in eliciting internode elongation. In addition, we have found two specific expressed proteins in vine plants, which may be associated with growth and differentiation.

\section{Literature Cited}

Birecka, H. and A.W. Galston. 1970. Peroxidase ontogeny in a dwarf pea stem as affected by gibberellin and decapitation. J. Expt. Bot. 21:735-745. 
Bradford, M.M. 1976. A rapid and sensitive method for the quantitation of microgram quantities of protein using the principle of proteindye binding. Ann. Biochem. 72:248-254.

Brewbaker, J.L., M.D. Upadhya, Y. Makinen, and T. MacDonald. 1968. Isoenzyme polymorphism in flowering plants. III. Gel electrophoretic methods and applications. Physiol. Plant. 21:930-940.

Campa, A. 1991. Biological roles of plant peroxidases; known and potential function, p. 25-50. In: J. Everse, K.E. Everse, and M.B. Grisham (eds.). Peroxidases in chemistry and biology, Vol. 11. CRC Press, Boca Raton, Fla.

Cao, J.S., H.F. Yu, W.Z. Ye, X.L. Yu, L.C. Liu, Y.Q. Wang, and X. Xiang. 2005. Identification and characterization of a gibberellinrelated dwarf mutant in pumpkin (Cucurbita moschata). J. Hort. Sci. Biotechnol. 80:29-31.

Evans, J.J. and N.A. Alldridge. 1965. The distribution of peroxidases in extreme dwarf and normal tomato (Lycopersicon esculentum Mill.). Phytochemistry 4:499-503.

Gaspar, T., C. Kevers, C. Penel, H. Greppin, D. Reid, and T. Thorpe. 1996. Plant hormones and plant growth regulators in plant tissue culture. In Vitro Cell Dev. Plants 32:272-289.

Kamerbeek, G.A. 1956. Peroxidase content of dwarf types and giant types of plants. Acta Botan. Neerland. 5:257-263.

Laemmli, U.K. 1970. Cleavage of structural proteins during the assembly of the head of bacteriophage T4. Nature 227:680-685.

Loy, J.B. 1967. Peroxidase and differentiation in cucurbits. Colo. State Univ., Fort Collins. PhD Diss.

Loy, J.B. 1972. A comparison of stem peroxidase in bush and vine forms of squash (Cucurbita maxima Duch. and C. pepo L.). J. Expt. Bot. 23:450-457.
Maehly, A.C. and B. Chance. 1954. The assay of catalase and peroxidase, p. 357-424. In: D. Glick (ed.). Methods of biochemical analysis, Vol. 1. Interscience, New York.

McCune, D.C. 1961. Multiple peroxidases in corn. Ann. N.Y. Acad. Sci. 94:723-730.

McCune, D.C. and A.W. Galston. 1959. Inverse effects of gibberellin on peroxidase activity and growth in dwarf strains of peas and corn. Plant Physiol. 34:416-418.

Passardi, F., C. Penel, and C. Dunand. 2004. Performing the paradoxical: How plant peroxidases modify the cell wall. Trends Plant Sci. 9:534-540.

Savitsky, P.A., I.G. Gazaryan, V.I. Tishkov, L.M. Lagrimini, T. Ruzgas, and L. Gorton. 1999. Oxidation of indole-3-acetic acid by dioxygen catalysed by plant peroxidases: Specificity for the enzyme structure. Biochem. J. 340:579-583.

Shanan, S.A. 1976. The effect of gibberellic acid on lignification and peroxidase activity in dwarf bean. Scientia Hort. 5:297-302.

Siegel, B.Z. and A.W. Galston. 1967. The isoperoxidases of Pisum sativum. Plant Physiol. 42:221-226.

Siegel, S.M. 1955. The biochemistry of lignin formation. Physiol. Plant. 8:20-32.

Van Overbeek, J. 1935. The growth hormone and the dwarf type of growth in corn. Proc. Natl. Acad. Sci. USA 21:292-299.

Wu, T., J.H. Zhou, Y.F. Zhang, and J.S. Cao. 2007. Characterization and inheritance of a bush-type in tropical pumpkin (Cucurbita moschata Duchesne). Scientia Hort. 114:1-4.

Yu, J.Q. and Y. Matsui. 1997. Effects of root exudates of cucumber (Cucumis sativus L.) and allelochemicals on ion uptake by cucumber seedling. J. Chem. Ecol. 23:817-827. 